Review

\title{
An Inside Job: Molecular Determinants for Postsynaptic Localization of Nicotinic Acetylcholine Receptors
}

\author{
Michael Ferns (D) \\ Departments of Anesthesiology \& Pain Medicine, and Physiology \& Membrane Biology, \\ University of California Davis, Davis, CA 95616, USA; mjferns@ucdavis.edu
}

check for updates

Citation: Ferns, M. An Inside Job: Molecular Determinants for Postsynaptic Localization of Nicotinic Acetylcholine Receptors. Molecules 2021, 26, 3065. https://doi.org/ $10.3390 /$ molecules 26113065

Academic Editor: Roger L. Papke

Received: 30 April 2021

Accepted: 15 May 2021

Published: 21 May 2021

Publisher's Note: MDPI stays neutral with regard to jurisdictional claims in published maps and institutional affiliations.

Copyright: (C) 2021 by the author. Licensee MDPI, Basel, Switzerland. This article is an open access article distributed under the terms and conditions of the Creative Commons Attribution (CC BY) license (https:// creativecommons.org/licenses/by/ $4.0 /)$.

\begin{abstract}
Nicotinic acetylcholine receptors (nAChRs) mediate fast synaptic transmission at neuromuscular and autonomic ganglionic synapses in the peripheral nervous system. The postsynaptic localization of muscle $\left((\alpha 1)_{2} \beta 1 \gamma \delta\right)$ and neuronal $\left((\alpha 3 \beta 4)_{2} \beta 4\right)$ nicotinic receptors at these synapses is mediated by interactions between the $\mathrm{nAChR}$ intracellular domains and cytoplasmic scaffolding proteins. Recent high resolution structures and functional studies provide new insights into the molecular determinants that mediate these interactions. Surprisingly, they reveal that the muscle nAChR binds 1-3 rapsyn scaffolding molecules, which dimerize and thereby form an interconnected lattice between receptors. Moreover, rapsyn binds two distinct sites on the nAChR subunit cytoplasmic loops; the MA-helix on one or more subunits and a motif specific to the $\beta$ subunit. Binding at the latter site is regulated by agrin-induced phosphorylation of $\beta Y 390$, and increases the stoichiometry of rapsyn/AChR complexes. Similarly, the neuronal nAChR may be localized at ganglionic synapses by phosphorylation-dependent interactions with 14-3-3 adaptor proteins which bind specific motifs in each of the $\alpha 3$ subunit cytoplasmic loops. Thus, postsynaptic localization of $\mathrm{nAChRs}$ is mediated by regulated interactions with multiple scaffolding molecules, and the stoichiometry of these complexes likely helps regulate the number, density, and stability of receptors at the synapse.
\end{abstract}

Keywords: neuromuscular junction; autonomic synapse; cholinergic synapse; receptor localization; structural motif; binding partner; scaffolding protein

\section{Introduction}

Nicotinic acetylcholine receptors (nAChRs) are ligand-gated ion channels belonging to the cys-loop superfamily that includes $\mathrm{GABA}_{\mathrm{A}}$, glycine, and $5 \mathrm{HT}_{3}$ serotonin receptors. In the peripheral nervous system (PNS), nAChRs mediate fast synaptic transmission at neuromuscular and autonomic ganglionic synapses, where they are localized in the postsynaptic membrane [1]. In the CNS, nAChRs mediate diverse and mainly neuromodulatory functions and are usually localized in presynaptic terminals where they modulate the release of neurotransmitters such as glutamate, GABA, and norepinephrine [2,3]. Thus, nAChRs play important roles in the functioning of both the peripheral and central nervous systems [3,4]. Consistent with this, dysfunction of nAChRs is a contributing factor or the direct cause of a variety of human neurological disorders. In the neuromuscular system, autoimmune antibodies to the $\mathrm{nAChR}$ lead to myasthenia gravis [5], and genetic mutations in the nAChR cause congenital myasthenic syndrome (CMS) [6], both of which are characterized by impaired synaptic transmission and muscle weakness. In the CNS, mutations in the neuronal $\mathrm{nAChR}$ cause autosomal dominant nocturnal frontal lobe epilepsy, and declines in nAChR expression contribute to Alzheimer's disease, Parkinson's disease, and schizophrenia (reviewed in [3,4,7]). Moreover, nAChRs mediate the effects of nicotine and upregulation of receptors occurs as part of tobacco addiction.

Nicotinic AChRs are pentameric channels that occur in multiple subtypes, formed from different combinations of subunits that convey different pharmacological and physiological properties [2,7]. The subunits are subdivided into two groups: Alpha subunits 
$(\alpha 1-10)$ which contain conserved cysteine residues in the extracellular domain and function in ligand binding, and non-alpha subunits $(\beta 1-4, \gamma, \delta$, and $\varepsilon)$ which function as accessory subunits. Muscle $\mathrm{nAChR}$ at the neuromuscular junction (NMJ) is composed of $2 \alpha$, and one $\beta, \delta$, and $\gamma$ (fetal) or $\varepsilon$ (adult) subunits. Neuronal nAChR are either homo-pentamers composed of $\alpha 7, \alpha 8$ or $\alpha 9$ subunits or hetero-pentamers composed of $\alpha 2-\alpha 6$ and $\beta 2-\beta 4$ subunits. Different combinations of alpha and beta subunits generate neuronal $\mathrm{nAChRs}$ with diverse stoichiometries although all receptors contain 2-3 alpha subunits. These differences in channel subunit composition are thought to play important roles in modulating the gating and biophysical properties of the channels, as well as the protein interactions involved in their trafficking and localization.

Alpha and non-alpha subunits share considerable homology and all subunits have a similar structure consisting of a large extracellular N-terminal domain, four transmembrane domains that form the central channel pore, and a large cytoplasmic loop between transmembrane domains 3 and 4 . The structure and function of the extracellular and pore domains of nicotinic acetylcholine receptors are discussed in detail in other articles in this issue. The focus of this article is to review the structure of the intracellular domain and its role in mediating the postsynaptic localization of nicotinic receptors at fast cholinergic synapses in the PNS [4,8]. The main emphasis is on muscle nAChRs, for which the molecular basis for localization is best understood. However, neuronal nAChRs are also briefly reviewed in order to point out some intriguing parallels, and differences, in their mode of postsynaptic localization.

\section{Structure of the $\mathrm{nAChR}$ Intracellular Domain}

Nicotinic receptor subunits contain two cytoplasmic loops; a short loop (of $\sim 8$ aminoacids) between TM1 and TM2 and a large loop of between 110 and 150 amino-acids between TM3 and TM4. The TM1-2 loop is relatively conserved, whereas the TM3-4 loop is the most divergent region between different receptor subunits (for a review, see [9]). For the TM3-4 loop, the greatest similarity between subunits lies in the proximal part of the loop following TM3 and the distal part of the loop prior to TM4, which both contain predicted alpha-helical secondary structures (Figure 1A). The intervening, mid-section of the loop is more variable in length and sequence in different subunits and meaningful alignments cannot be made for this region. Notably, however, some receptor subunits contain stretches of amino acids in the central loop region that are highly conserved across species (Figure 1B), suggesting that important subunit-specific functions may be mediated by these motifs [9].

High resolution structures have now been obtained for several members of the cysloop family including the muscle nAChR (Figure 1C) [10-12] neuronal $\alpha 4 \beta 2, \alpha 3 \beta 4$, and $\alpha 7$ nAChRs [13-15], GABA $\mathrm{A}_{\mathrm{A}}$ receptor [16], glycine $\alpha 3$ receptor [17], and $5 \mathrm{HT}_{3}$ receptor [18]. These reveal a conserved architecture of the channel and constituent subunits $[19,20]$, as well as providing new insights into the structural basis of transmitter binding and channel gating. One region that is absent or only partially resolved in these structures, however, is the large cytoplasmic loop domain of each subunit (Figure 1C). Although structural information is limited, two separate alpha helices have been identified in the large cytoplasmic loop of some cys-loop receptors. The MX-helix is apparent in high resolution structures of the $5 \mathrm{HT}_{3}$ receptor and muscle and neuronal nAChRs, and is present in all subunits of those pentamers $[11,15,16,19]$. This short helix ( 13 amino acids) lies just after TM3 and is positioned laterally in the proximal TM3-4 cytoplasmic loop (Figure 1C), placing it in close proximity to the inner leaflet of the plasma membrane. Interestingly, it ends near the interface with the adjacent receptor subunit and may contribute to the cytoplasmic interface between subunits. The MA-helix was first resolved in structures of the muscle $\mathrm{nAChR}$ derived from cryo-electron microscopy [12], and later confirmed in high resolution structures of the $5 \mathrm{HT}_{3}$ receptor and neuronal $\mathrm{nAChRs}[11,15,16,19]$. This long, amphipathic helix lies in the distal portion of the cytoplasmic loop and is continuous with the TM4 helix (Figure 1C,D). The MA helices of each subunit extend approximately $40 \AA$ down from the plasma membrane and frame a conical intracellular vestibule that 
lies beneath the channel pore. Interestingly, this vestibule contains lateral portals for ion efflux near TM4 and charged residues in this region contribute to the ion selectivity of the channel $[10,21]$.

A

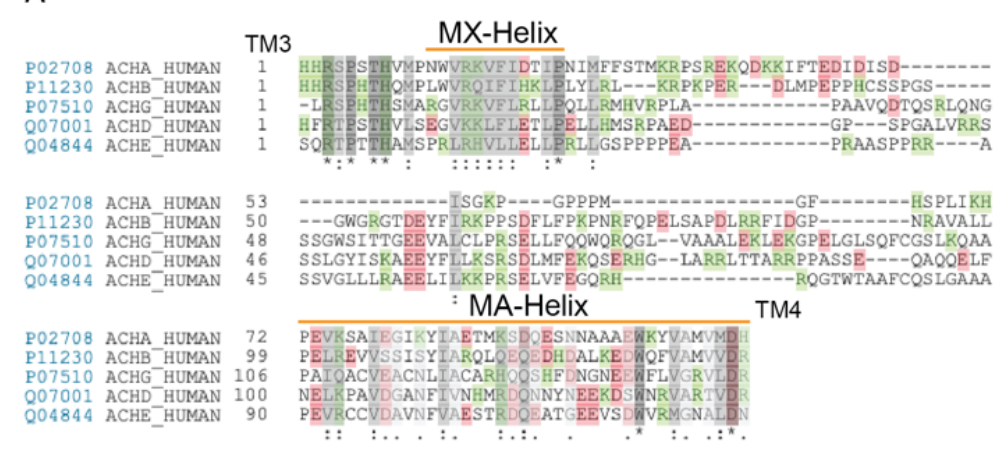

C

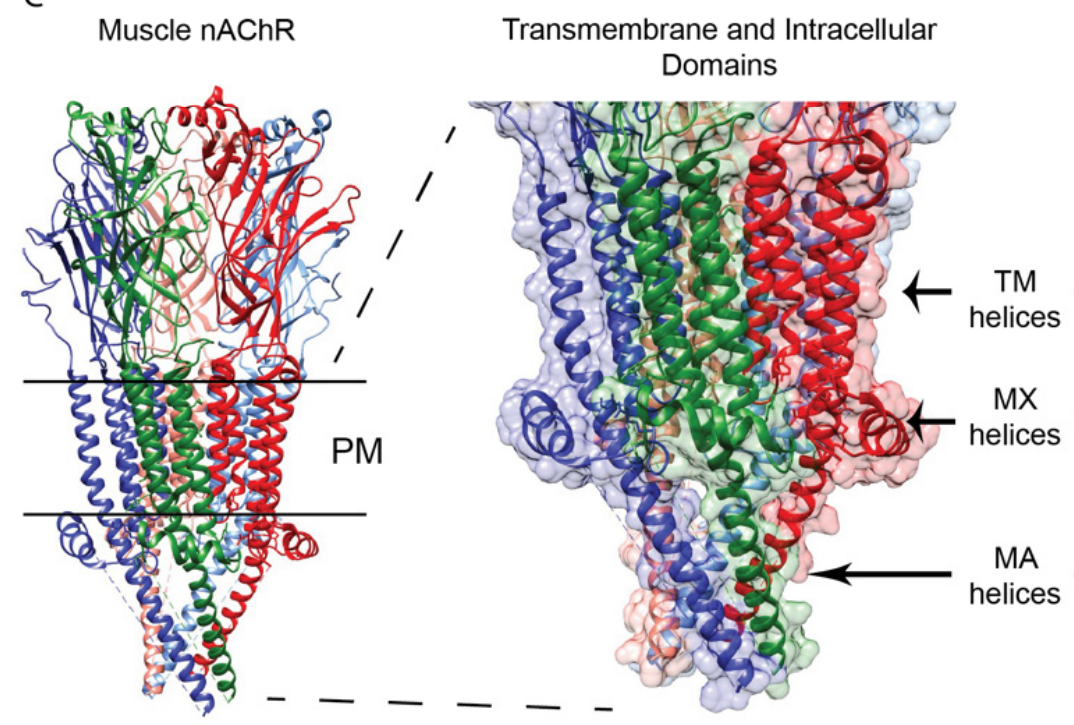

B

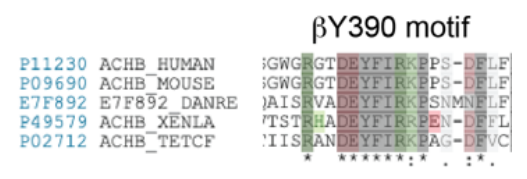

D

Beta subunit

Figure 1. Structure of the muscle nAChR intracellular domains. (A) A sequence alignment of the muscle nAChR subunit large cytoplasmic loops between transmembrane domains 3 and 4 . The greatest similarity between subunits occurs in the proximal and distal portions of the loop, which contain the MX- and MA- $\alpha$-helices, respectively (green and red colors denote positively and negatively charged amino acids, respectively. Identical residues are denoted by * and conserved and semi-conserved substitutions by : and . respectively. (B) The mid-portion of some subunit loops contain motifs that are highly conserved across species, such as the sequence surrounding $\beta$ subunit tyrosine 390 (Y390). (C) A high resolution structure of the Torpedo (muscle-type) nAChR (PDB: 6UWZ), with an enlarged view of the transmembrane and intracellular domains is shown to the right (red, $\alpha$ subunit; green, $\beta$; blue, $\delta$ ). All subunits contain an MX-helix that is positioned laterally near the plasma membrane, and an MA-helix that extends $\sim 40 \AA \AA$ down from the membrane. The mid-portion of each subunit loop is not resolved and presumed to be disordered. (D) A corresponding view of the $\beta$ subunit alone, shows the MX and MA-helices and the missing intervening structure $\left(^{* *}\right)$ (abbreviations: PM: Plasma membrane; TM: Transmembrane; ICD: Intracellular domain).

The structure of the intervening sequence between the MX and MA helices is not resolved for any cys-loop receptor subunits and is likely disordered, as suggested from secondary structure predictions. Several highly conserved phosphorylation sites and antibody binding sites map to this mid-loop region in some muscle and neuronal nAChR subunits, suggesting it is partially solvent-exposed, and able to interact with kinases and possibly other cytoplasmic proteins. 


\section{Postsynaptic Localization of the Muscle nAChR}

The muscle nAChR mediates fast synaptic transmission at the NMJ on skeletal muscle fibers. Transmission at this synapse is rapid and reliable, with a large safety factor under normal physiological conditions. This stems from the immense size of the NMJ, where an action potential triggers the release of many synaptic vesicles $(\sim 25-50)$ at multiple active zones in the presynaptic motor nerve terminal. In addition, the muscle nAChR is localized at an extremely high density $\left(\sim 10,000\right.$ per $\left.\mu \mathrm{m}^{2}\right)$ at the top of the postsynaptic junctional folds. Consequently, the released acetylcholine directly gates thousands of postsynaptic nAChRs, evoking a large depolarization (endplate potential) that exceeds the threshold and triggers an action potential in the muscle fiber. The number and density of $n A C h R s$ is a key determinant of synaptic efficacy, therefore, and defects in nAChR expression in genetic and autoimmune diseases impair transmission and result in myasthenia [22,23]. Not surprisingly, therefore, the expression levels of $\mathrm{nAChR}$ at the $\mathrm{NMJ}$ are tightly regulated and reflect multiple mechanisms including clustering, anchoring, and stabilization of receptors in the postsynaptic membrane [8]. These processes are controlled by specific protein interactions between molecular determinants in the acetylcholine receptor and postsynaptic scaffolding and signaling proteins. In the vertebrate $\mathrm{nAChR}$, the molecular determinants that regulate these inter-related aspects of receptor localization lie within the major cytoplasmic TM3-4 loop.

The specific, high density localization of nAChRs in the postsynaptic membrane is established during formation of the NMJ and is regulated by a nerve-derived signal called agrin. During synapse formation, motoneuron-derived agrin signals via a receptor complex on muscle cells consisting of the MuSK receptor tyrosine kinase [24] and LRP4 co-receptor $[25,26]$ to induce and/or maintain $\mathrm{nAChR}$ clusters at nerve-muscle contacts. This occurs via a complex signaling pathway that includes Dok7 [27,28], Tid1 [29], crk [30], pak [31], and the small GTPases, Rac, cdc42, and Rho [32,33]. Indeed, mice with targeted deletions of agrin, MuSK, LRP4, and Dok7 all fail to form functional NMJs and die shortly after birth [28,34-36]. Intriguingly, the nerve-evoked activity has an antagonistic role to agrin during synapse formation, and disperses prepatterned $\mathrm{nAChR}$ aggregates that are not contacted by nerve terminals [37-41].

\subsection{AChR Localization Is Mediated by Rapsyn}

The key downstream component of the agrin signaling pathway that mediates nAChR localization is the peripheral membrane protein rapsyn. Rapsyn colocalizes precisely with the AChR in Torpedo electric organ and at developing and adult vertebrate NMJs [42-44]. Moreover, biochemical studies on purified synaptic membranes from the Torpedo electric organ estimate that the stoichiometry of rapsyn to AChR is in the range of $0.5-2[45,46]$. When expressed in heterologous cells, rapsyn self-aggregates and co-clusters the $\mathrm{nAChR}$ as well as several other postsynaptic proteins on the cell surface [47,48]. Conversely, in rapsyn-deficient mice, the $\mathrm{nAChR}$ and several other proteins fail to cluster at the NMJ, resulting in non-functional synapses and perinatal lethality [49]. Multiple mutations in the RAPSN gene have also been identified in humans that cause congenital myasthenic syndrome. These mutations typically result in decreased $\mathrm{nAChR}$ levels at the synapse and thereby impair neuromuscular transmission and muscle function [50,51]. Thus, rapsyn is sufficient for $\mathrm{nAChR}$ clustering in vitro and necessary for $\mathrm{nAChR}$ localization at the NMJ in vivo.

Rapsyn is a $43 \mathrm{kD}$ protein with a predicted domain structure that includes a myristylation signal at the $\mathrm{N}$-terminus that targets it to the membrane, seven tetratricopeptide repeats, a coiled-coil domain, a RING-H2 domain, and a C-terminus containing highly conserved serine phosphorylation sites. The functional analysis using rapsyn deletion constructs expressed in heterologous cells suggest that the seven tetratricopeptide repeats mediate rapsyn self-association [52,53], the coiled-coil domain interacts with the nAChR [52], and the cysteine-rich RING structure interacts with scaffold proteins and also has E3 ligase activity [54]. However, this functional analysis of rapsyn's domains is inconsis- 
tent with the defects observed in several rapsyn CMS mutants (reviewed in [55,56]), and the rapsyn domains that mediate many of its key interactions, including binding the nAChR, await further confirmation. In addition, rapsyn binds the MuSK- [57] and dystroglycanbased transmembrane scaffolds [58,59], as well as multiple cytoskeletal-associated proteins including alpha-actinin [60], MACF1 [61,62], and plectin-1f [63]. Taken together, these findings suggested a model in which rapsyn binds the nAChR with 1:1 stoichiometry and recruits it to a stable postsynaptic scaffold established by rapsyn dimerization and rapsyn links to other postsynaptic scaffolding and cytoskeletal proteins. While this simple model has prevailed for over 25 years, recent studies suggest that nAChR localization occurs through considerably more complex and regulated rapsyn interactions.

\subsection{AChR-Rapsyn Stoichiometry}

A large body of evidence has now accumulated and converged to demonstrate that rapsyn interacts with the $n A C h R$ in a regulated and variable stoichiometry of $\geq 2: 1$, rather than an invariant 1:1 interaction. First, nAChR initially associates with rapsyn in the late secretory pathway and they are co-transported as a pre-formed complex to the cell surface [64-66]. Indeed, rapsyn transport to the plasma membrane (PM) is dependent on the $\mathrm{nAChR}$ and rapsyn is retained in the Golgi apparatus in myoblasts and zebrafish mutants that lack the receptor $[67,68]$. Pre-formed rapsyn/nAChR complexes do not automatically aggregate on the cell surface, however, and remain diffusely distributed in denervated muscle or cultured myotubes [69]. Thus, $\mathrm{nAChR}$ clustering requires either additional signals that induce rapsyn dimerization [70], and/or binding of additional rapsyn molecules to the receptor. Second, it was found that the ratio of rapsyn to $\mathrm{nAChR}$ increases during maturation of the NMJ [71,72], and that overexpression of rapsyn in muscle stabilizes and increases the packing density of the $\mathrm{nAChR}$ [73]. This implies that additional rapsyn molecules can be recruited to free sites on the $\mathrm{nAChR}$, although rapsyn binding to other proteins cannot be discounted. Third, rapsyn has been shown to interact with multiple receptor subunits in heterologous cell expression experiments [74-76], suggesting that several rapsyn binding sites are available on the receptor. Fourth, several groups found that agrin-MuSK signaling increases the amount of rapsyn associated with surface $\mathrm{nAChR}$ by around 1.7-fold [69,77-79]. As the amount of $\mathrm{nAChR}$ co-immunoprecipitated with rapsyn does not increase, this argues for an increase in the number of rapsyn molecules bound to each receptor, rather than an increase in their binding affinity. Fifth, a cryo-electron tomography study of Torpedo postsynaptic membranes detected 1-3 rapsyn molecules per receptor, which form an interconnected lattice between nAChRs [80]. Taken together, these studies provide compelling evidence that rapsyn binds the $\mathrm{nAChR}$ with a regulated and variable stoichiometry of $\geq 2: 1$ to mediate its postsynaptic localization.

\subsection{The $n A C h R$-Rapsyn Binding Sites}

Attempts to identify the specific determinants in the nAChR subunit cytoplasmic loops that bind rapsyn have proven extremely difficult for a number of reasons. Multiple binding sites create redundancy in rapsyn/nAChR association, and deletions or mutations within the cytoplasmic loops often impair receptor assembly and surface expression. These issues mask or prevent the identification of rapsyn binding sites on intact nAChR. Biochemical approaches using isolated loop fragments have also been hampered by rapsyn's notorious insolubility and tendency to self-aggregate. To circumvent these issues our group utilized chimeric proteins consisting of the CD4 single-pass transmembrane protein fused to the large cytoplasmic loop of each nAChR subunit to map rapsyn's binding sites. This approach has been used in multiple studies to express isolated cytoplasmic domains of ion channels at the plasma membrane, and to map their targeting and localization signals and protein interactions [81,82]. When expressed in heterologous cells, we found that rapsyn clustered and cyto-skeletally anchored CD4- $\alpha, \beta$, and $\varepsilon$ subunit loops, although with different efficiencies [76]. Rapsyn interacted most strongly with the $\beta$ subunit, which is consistent with previous cross-linking [46] and yeast two-hybrid studies [58] that also identified an 
interaction between rapsyn and the $\beta$ subunit. Using $\beta$ loop fragments, the rapsyn binding site was mapped to the MA $\alpha$-helix in the C-terminal portion of the loop, and this interaction was independent of agrin signaling in muscle cells [76]. The MA $\alpha$-helical structure is present in all muscle nAChR subunits, although there is only moderate similarity in the primary sequence of the $\alpha$-helix in different subunits (Figure 1A). Together with the observation that rapsyn interacts more strongly with the complete MA-helix compared to its first or second halves, this suggests that rapsyn likely recognizes structural features of the helix rather than a specific amino acid sequence. This would also explain why rapsyn can interact with multiple muscle $n A C h R$ subunits, and even with some other members of the cys-loop receptor family such as $\alpha 4 \beta 2$ and $\alpha 7 \mathrm{nAChRs}[83,84]$ and $\mathrm{GABA}_{\mathrm{A}}$ receptors [85], which possess analogous MA helices. These findings identify up to four potential rapsyn-MA-helix binding sites on the AChR, but it remains unclear how many are actually utilized and if they are required for AChR localization. Unfortunately, it is not possible to delete or mutate the MA-helix of multiple subunits as this prevents receptor assembly. However, a three codon deletion in the $\beta$ loop $\alpha$-helix has been linked to a congenital myasthenic syndrome with severe nAChR deficiency that is consistent with both the defective interaction with rapsyn and impaired assembly [86]. Moreover, overexpression of a soluble MA-helix fragment in cultured muscle cells prevents agrininduced clustering of the nAChR [87]. Thus, it seems likely that rapsyn binding to the MA helix of one or more subunits plays a critical role in postsynaptic aggregation of the nAChR. In addition to the MA-helix, a distinct and regulated rapsyn binding site has also been identified on the nAChR $\beta$ subunit. Remarkably, when CD4-subunit loop chimeras are individually expressed in cultured muscle cells, only CD4- $\beta$ loop is recruited to agrin-induced AChR clusters [77]. Progressive deletions within the $\beta$ loop identified a 20 amino-acid sequence that was sufficient for postsynaptic localization and this sequence contains a highly conserved tyrosine residue whose phosphorylation is induced by agrin signaling [88]. Indeed, agrin-induced phosphorylation of $\beta Y 390$ induced rapsyn binding to the $\beta$ loop motif, and conversely mutation of Y390 abolished both clustering of the CD4- $\beta$ loop fragment and its interaction with rapsyn. In analogous experiments on intact AChR in muscle cells, agrin increased the ratio of rapsyn binding to wild type $\mathrm{nAChR}$ but not to $\mathrm{nAChR}$ with a mutated $Y 390$ phosphorylation site $\left(\mathrm{AChR}-\beta^{3 \mathrm{~F}} / 3 \mathrm{~F}\right)$ [77]. Together, these findings identify a 20 amino-acid motif in the first half of the $\beta$ subunit cytoplasmic loop which forms a distinct, phosphorylation-dependent binding site for rapsyn. As might be expected given that rapsyn also binds the nAChR subunit MA-helix, rapsyn binding to the $\beta Y 390$ motif is not essential for $\mathrm{nAChR}$ localization at the NMJ. Notably, however, AChR- $\beta^{3 \mathrm{~F} / 3 \mathrm{~F}}$ knock-in mice have simplified and smaller NMJs with a significantly reduced density and number of postsynaptic nAChRs [89]. Thus, regulated binding of rapsyn to this distinct site on the proximal $\beta$ subunit cytoplasmic loop clearly contributes to $n A C h R$ localization.

Additional, compelling evidence for multiple rapsyn binding sites on the nAChR comes from structural studies of Torpedo electric organ, a model system for the NMJ. In a $4.6 \AA$ structure of $n A C h R /$ rapsyn complexes derived from electron microscopy images of tubular Torpedo membranes, rapsyn showed a 2-fold symmetry, implying two rapsyn molecules associated with a single nAChR $[11,90]$. Similarly, cryo-electron tomography and subtomogram averaging of Torpedo postsynaptic membranes showed that $\mathrm{nAChRs}$ are connected by up to three rapsyn bridges [80]. The rapsyn molecules bind at three stereotyped positions on the $\mathrm{nAChR}$, although the resolution $(\sim 4 \mathrm{~nm})$ was not sufficient to identify the receptor subunits involved (Figure 2A). Sites I and II appear to be homologous and likely occur on adjacent subunits, as they are separated by $72^{\circ}$ in the pentamer. Site III appears distinct as it is located closer to the membrane and is separated from site I by $108^{\circ}$. The occupancy of each site varied between nAChRs, with binding at site II being the most common. The rapsyn lobes associated with each nAChR also occurred in two classes, whose size is consistent with a rapsyn monomer and dimer, respectively. In most cases, however, rapsyn dimers were observed connecting adjacent receptors and thereby creating an inter-connected lattice of $\mathrm{nAChRs}$ in the postsynaptic membrane. These 
findings suggest that up to three rapsyn binding sites are utilized on the nAChR, which fall in two classes [80]. The simplest possibility is that the homologous sites (I and II) correspond to the MA helix on adjacent subunits, and that the non-homologous site (III) corresponds to the $\beta Y 390$ motif (Figure 2B). However, this raises the question of why rapsyn binds only two of the four potential MA helix sites that were identified on the alpha, beta, and epsilon subunits. One possible explanation is that rapsyn binds to the MA helices at the interface between subunits and this confers additional specificity to the interaction that restricts binding to two sites on the nAChR.

A

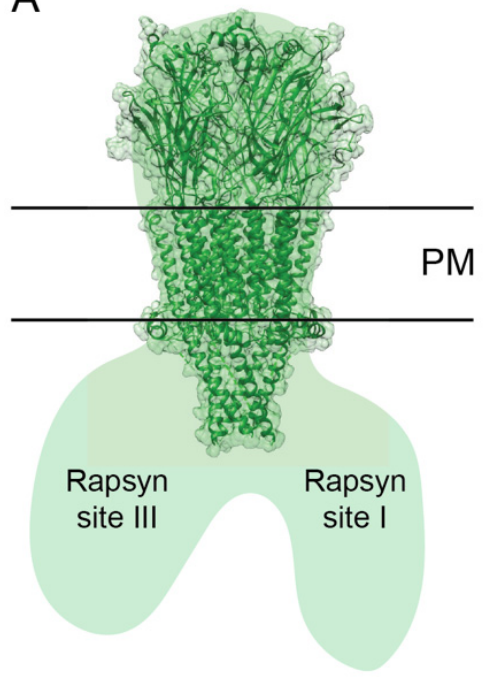

B

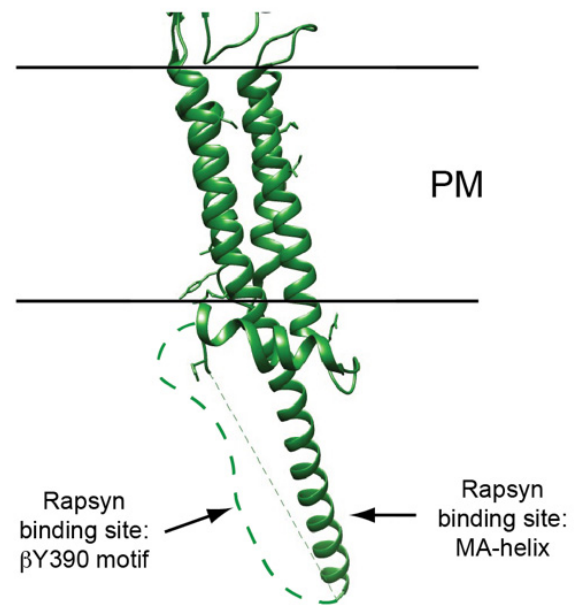

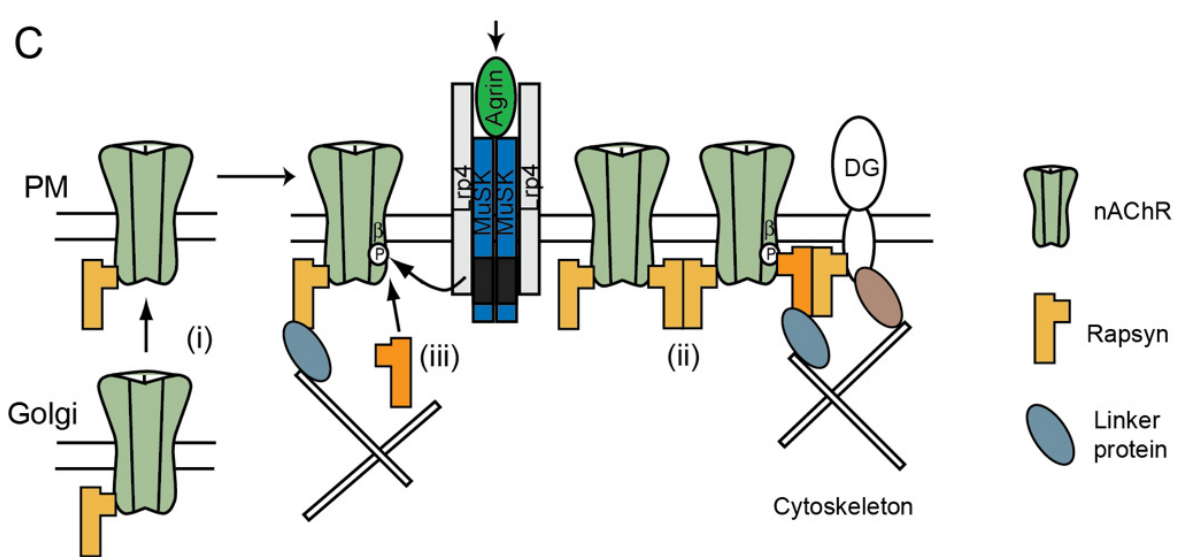

Figure 2. nAChR-rapsyn binding sites. (A) Structural studies on Torpedo synaptic membranes showed that each nAChR is associated with 1-3 rapsyn molecules, which bind at two homologous sites on adjacent subunits (site I and II), and a non-homologous site on the opposing face of the receptor (site III) [80]. (B) Complementary studies using subunit loop chimeric proteins identified rapsyn binding sites on the MA-helices and a phosphorylation-dependent binding site on the conserved $\beta Y 390$ motif. (C) These findings suggest a revised model where rapsyn localizes the $\mathrm{nAChR}$ in the postsynaptic membrane via multiple, regulated interactions. Rapsyn associates with the nAChR in the Golgi apparatus (i) and they exist as pre-formed complexes on the PM. Agrin-MuSK signaling induces their co-clustering via rapsyn dimerization (ii) and by binding of an additional rapsyn molecule to the phosphorylated $\beta Y 390$ motif (iii). Recruitment of additional rapsyn may require a chaperone protein (not shown). These two mechanisms create rapsyn bridges between $\mathrm{nAChRs}$ and also anchor receptors to transmembrane and cytoskeletal scaffolding proteins. Thus, the stoichiometry of rapsyn $/ \mathrm{nAChR}$ complexes is an important determinant of the density and stability of nAChRs in the postsynaptic membrane. 
Although the specific subunits that interact with rapsyn remain to be defined, these findings further support a more complex model for nAChR localization where rapsyn$n A C h R$ association occurs via two distinct sites and with a variable stoichiometry of $\geq 2: 1$ (Figure 2C). It also raises the possibility that rapsyn binding to each site has differing functions, which combine to localize the receptor in the postsynaptic membrane.

\subsection{Function of $n A C h R-R a p s y n$ Interactions}

Rapsyn mediates nAChR localization at developing NMJs through multiple mechanisms, including clustering, anchoring, and metabolic stabilization of the nAChR. These inter-related functions are regulated by agrin-MuSK signaling, and likely relate to the site and stoichiometry of rapsyn binding to the receptor. First, rapsyn's clustering of nAChR in the PM is thought to be due to its ability to dimerize and thereby cross-link pre-formed rapsyn/nAChR complexes (Figure 2C). Higher ratios of rapsyn molecules per AChR would increase the number of cross-links between nAChRs, leading to an increase in the packing density. Indeed, increased receptor density has been observed with rapsyn overexpression in mouse muscle [71,73], and decreased density is observed in $\mathrm{AChR}-\beta^{3 \mathrm{~F}} / 3 \mathrm{~F}$ knock-in mice that lack the phosphorylation-dependent $\beta Y 390$ binding site for rapsyn [89]. Similarly, $n A C h R$ packing density in purified Torpedo synaptic membranes also correlates with rapsyn abundance [80]. Second, rapsyn anchors the $\mathrm{nAChR}$ to several components of the postsynaptic cytoskeleton and also to transmembrane scaffolding proteins $[35,57,59-$ 62,91]. Again, this is likely enhanced by higher stoichiometries of rapsyn binding, which could allow for more links to the postsynaptic scaffold (Figure 2C). Rapsyn binding to the $\beta Y 390$ motif may be especially important, as mutation of this site increases the detergent extractability of the receptor, implying that it is anchored less effectively to the postsynaptic cytoskeleton $[88,89]$. Third, rapsyn increases the metabolic stability of nAChR in cultured heterologous and muscle cells [92,93] and at the NMJ [71,73]. In heterologous cells this appears to be mediated by rapsyn binding to the MA-helix, as it does not require beta subunit tyrosine phosphorylation [92]. In muscle cells, agrin-induced stabilization of the $\mathrm{nAChR}$ requires $\beta Y 390$ phosphorylation but not clustering, suggesting that it involves rapsyn binding specifically to the Y390 motif [93]. Presumably both rapsyn interactions would combine to stabilize the nAChR and decrease its turnover at the NMJ (Figure 2C). Interestingly, rapsyn's own turnover is considerably more rapid $(\sim 3 \mathrm{~d})$ than that of the $\mathrm{nAChR}$ $(\sim 11-14 \mathrm{~d})$, placing it in a unique position to regulate receptor turnover [94,95]. Consistent with this, rapsyn levels and stability are regulated by multiple mechanisms including stabilization by binding to HSP90 3 [79] and CUL3/KLHL8-dependent ubiquitination and degradation by the proteasome [96].

The overall conclusion from these studies is that postsynaptic clustering, anchoring, and stabilization of the AChR are regulated in part by the stoichiometry of rapsyn/AChR complexes. While some functions may stem from a simple increase in the number of rapsyn molecules bound per $\mathrm{nAChR}$, other functions might require rapsyn binding to a specific site (MA helix or $\beta Y 390$ motif). In the latter case, conformational differences between rapsyn bound at each site could influence its possible protein binding partners and thereby its functional effects.

Adding further complexity to the rapsyn/nAChR story, recent findings suggest that rapsyn may also regulate $\mathrm{nAChR}$ clustering by an entirely novel mechanism. Rapsyn was found to have E3 ligase activity that is mediated by its C-terminal RING domain, and mutation of this domain abolishes rapsyn-mediated nAChR clustering in both heterologous and muscle cells [54]. Interestingly, rapsyn's E3 ligase activity mediates neddylation (a modification similar to ubiquitination) of the $\mathrm{nAChR} \delta$ subunit, and genetic and pharmacological manipulations that block neddylation, as well mutation of the main neddylation site in the $\delta$ subunit cytoplasmic loop all impaired $n A C h R$ clustering. These results are intriguing although the precise mechanism by which neddylation contributes to $\mathrm{nAChR}$ clustering remains unclear [70]. The simplest possibility is that the neddylated $\delta$ subunit forms a binding site for rapsyn or another scaffolding protein involved in receptor lo- 
calization. This seems unlikely, however, as no evidence has been obtained for higher molecular weight (i.e., neddylated) forms of $\delta$ subunit in postsynaptic nAChR isolated from muscle or agrin-treated muscle cell cultures or for neddylated proteins being localized at a high density at the NMJ. Consequently, it will be important to determine whether neddylation of the $\delta$ subunit regulates other processes such as trafficking and turnover of the nAChR, and if other proteins are also neddylated by rapsyn that are important for clustering. Interestingly, the major neddylation site on $\delta$ lies between a highly conserved agrin-induced tyrosine phosphorylation site ( -4 amino-acids) and two CMS mis-sense mutations which impair expression and/or clustering of receptor ( +2 and +8 amino-acids). This identifies this highly conserved region of the $\delta$ subunit loop as a possible component of a rapsyn binding site or a region that modulates rapsyn binding to adjacent subunit loops.

In summary, several independent lines of evidence have converged to show that multiple rapsyn molecules bind the nAChR subunit cytoplasmic loops to localize the receptor in the postsynaptic membrane. The stoichiometry of rapsyn/nAChR complexes is variable and regulated by agrin signaling, allowing for fine control over AChR clustering, anchoring, and stability. Several important questions remain, however, including which subunits or subunit interfaces are bound by rapsyn, and whether rapsyn binding to different sites nucleates specific rapsyn-scaffolding protein linkages with distinct functions.

\section{Postsynaptic Localization of Neuronal nAChRs}

The neuronal nAChR occurs in multiple subtypes with different subunit compositions that confer distinct functional properties and possibly different subcellular localizations. In the vertebrate $\mathrm{CNS}$, neuronal $\mathrm{nAChRs} \mathrm{have} \mathrm{diverse} \mathrm{and} \mathrm{mainly} \mathrm{neuromodulatory} \mathrm{functions,}$ and are often localized on presynaptic nerve terminals where they modulate the transmitter release. In the PNS, however, neuronal nAChRs mediate fast synaptic transmission at inter-neuronal synapses and are essential for autonomic function. These fast cholinergic synapses are mostly located in autonomic ganglia, where visceral motoneurons (preganglionic neurons) synapse onto sympathetic or parasympathetic postganglionic neurons. At these synapses, the neuronal $\mathrm{nAChR}$ is aggregated at a high density in the postsynaptic membrane and is composed predominantly of $\alpha 3, \alpha 5, \beta 2$, and $\beta 4$ subunits [97]. Notably, mice with a knockout of the $\alpha 3$ subunit or double knockout of the $\beta 2$ and $\beta 4$ subunits have severely reduced ganglionic transmission and multiorgan autonomic dysfunction, leading to significant postnatal mortality [98-100]. Homo-oligomers composed of $\alpha 7$ subunits also contribute to transmission at some peripheral synapses [101].

Although ganglionic synapses are functionally similar to neuromuscular synapses, surprisingly few parallels have been described regarding the signals that regulate their development or the scaffolding proteins that localize the nAChR at each synapse. Agrin's role is partially conserved as it helps direct neuronal synapse formation in sympathetic ganglia and adrenal medulla. Most notably, synaptic differentiation and transmission are impaired in superior cervical ganglia of agrin null mice [102,103], and agrin rapidly increases the strength of nicotinic transmission at developing sympathetic synapses on adrenal chromaffin cells by recruiting additional $\mathrm{nAChRs}$ to postsynaptic sites [104]. Synapses are not eliminated in agrin null ganglia as they are at the NMJ, however, indicating that additional synaptogenic factors contribute to the formation of cholinergic inter-neuronal synapses [105].

\section{Determinants for Neuronal nAChR Localization}

Downstream of these synapse-organizing factors, the molecular basis for neuronal $\mathrm{nAChR}$ localization at ganglionic synapses is poorly defined. This question was first addressed using chimeric nAChRs to identify the receptor subunits that mediated synaptic localization. In an elegant study, Michele Jacob's group showed that chimeric $\alpha 7 \mathrm{nAChRs}$ that contained the $\alpha 3$ but not $\alpha 5$ or $\beta 4$ large cytoplasmic loops were retargeted from perisynaptic regions to the postsynaptic membrane $[106,107]$. This demonstrates that the $\alpha 3$ cytoplasmic loop is sufficient for synaptic localization (Figure 3A), although as for the 
muscle $\mathrm{nAChR}$, it has proved challenging to define the motifs involved and to confirm that they are required for receptor localization. One intriguing possibility is a conserved consensus motif in $\alpha 3$ loop for binding of the 14-3-3 adaptor protein (Figure 3B,C). Indeed, 14-3-3 partially colocalizes with the $\mathrm{nAChR}$ at synapses in chick ciliary ganglia and associates biochemically with the receptor both in vivo and in vitro [108]. The 14-3-3 protein also interacts with adenomatous polyposis coli (APC), which organizes a postsynaptic scaffold that includes several microtubule-associated proteins and is important for $n A C h R$ surface expression [108,109]. Thus, 14-3-3 could link $\alpha 3-n A C h R$ to APC and thereby localize the $\mathrm{nAChR}$ in the postsynaptic membrane (Figure 3C). As 14-3-3 binding is often phosphorylation-dependent, phosphorylation of conserved serine residues in the motif could regulate binding of two 14-3-3 molecules to the nAChR (i.e., one to each of the $\alpha 3$ subunits in the pentamer). Moreover, as 14-3-3 proteins commonly form dimers, they could cross-link and cluster neuronal nAChRs in a manner analogous to rapsyn-induced clustering of muscle nAChRs (Figure 3D). While an attractive possibility, it remains to be shown that the 14-3-3 binding motif in $\alpha 3$ loop is either necessary and/or sufficient for receptor localization.

A

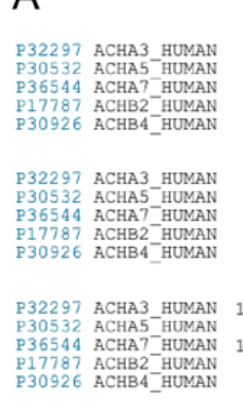

TM3

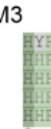

\section{MX-Helix}
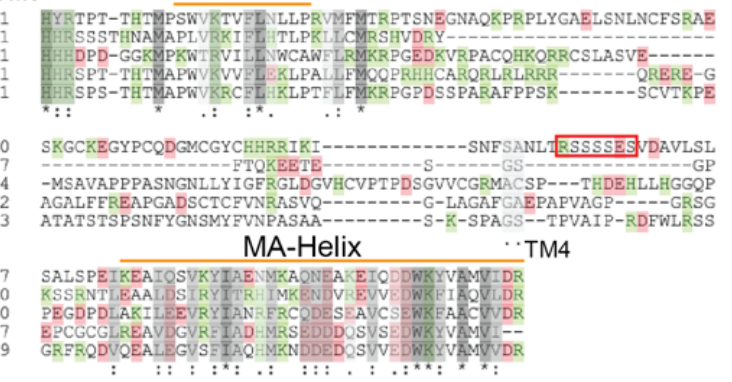

B

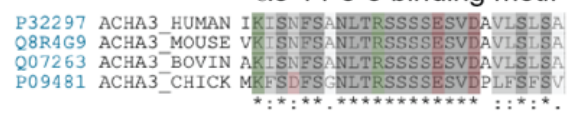

C

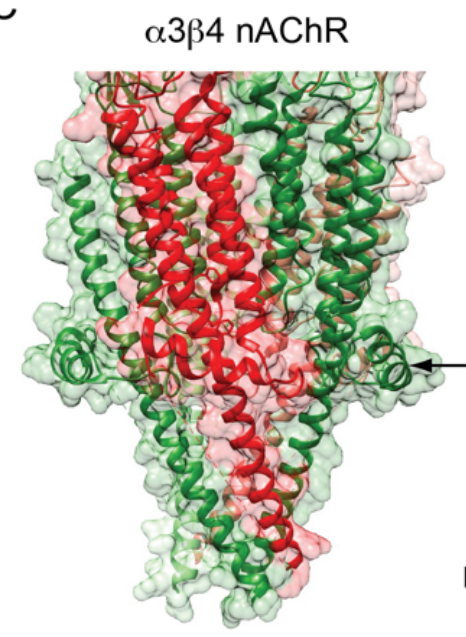

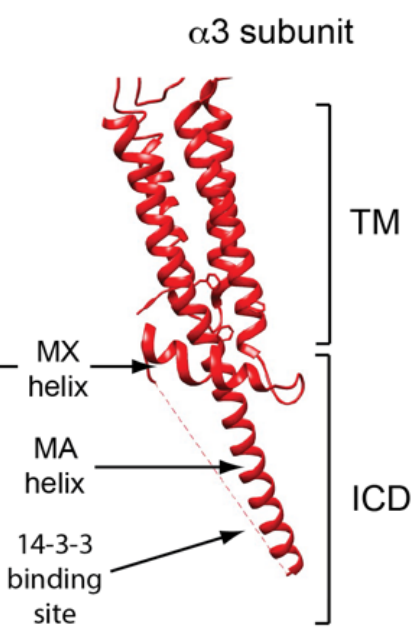

$\mathrm{D}$

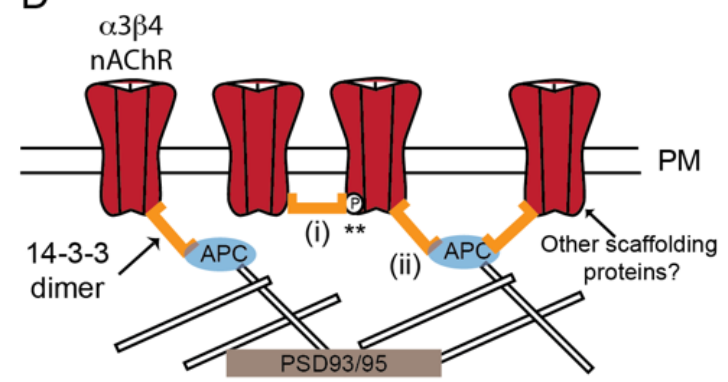

Figure 3. Determinants of neuronal nAChR postsynaptic localization. (A) A sequence alignment of the neuronal (ganglionictype) nAChR subunit large cytoplasmic loops between transmembrane (TM) domains 3 and 4 . The subunit loops share a moderate homology in their proximal and distal portions, but differ considerably in the central region. (B) The putative 14-3-3 binding motif in the mid-portion of $\alpha 3$ subunit loop is highly conserved across species (identical residues are denoted by * and conserved and semi-conserved substitutions by : and . respectively). (C) A high resolution structure of the neuronal $\alpha 3 \beta 4$ AChR (PDB: 6PV7) showing the transmembrane and intracellular domains. The large cytoplasmic loop of neuronal subunits has a similar structure to that of muscle $n A C h R$ subunits and contain analogous MX- and MA- $\alpha$-helices. (D) A speculative model for neuronal nAChR localization at ganglionic synapses. Binding of the 14-3-3 adaptor protein to the $\alpha 3$ subunit loop clusters the receptor in the postsynaptic membrane via 14-3-3 dimerization (i) and/or binding to APC and its associated cytoskeletal proteins (ii). Potentially, two 14-3-3 molecules could interact with the nAChR (one to each $\alpha 3$ subunit) and binding could be regulated by phosphorylation of the $\alpha 3$ loop motif $\left({ }^{* *}\right)$. Other scaffolding proteins could also contribute to receptor localization. 
In addition, based on the muscle nAChR model, it is possible that additional interactions could contribute to postsynaptic localization of neuronal nAChRs. For instance, other scaffolding proteins could bind the MA helix of one or more receptor subunits, in a manner analogous to rapsyn binding to the muscle nAChR. Interestingly, rapsyn can cluster neuronal nAChRs in heterologous cells but it is not localized at ganglionic synapses and $\mathrm{nAChR}$ remains aggregated at these synapses in rapsyn null mice [83,84]. Alternative scaffolding proteins include PSD93 and 95, which are both localized at ganglionic synapses, however they do not bind neuronal $\mathrm{nAChRs}$ directly and are dispensable for $\mathrm{nAChR}$ localization [110,111]. Similarly, APC does not bind neuronal $\alpha 3 \beta 4$ nAChRs directly [109], even though it binds muscle nAChRs via the $\beta 1$ subunit MA-helix [87]. Thus, APC and PSD93/95 help organize the postsynaptic scaffold rather than directly anchoring $\mathrm{nAChRs}$ at the synapse.

In summary: Many questions remain on how neuronal nAChRs are localized at cholinergic inter-neuronal synapses in the PNS. Most notably, is the $\alpha 3$ subunit $14-3-3$ binding motif required for $\mathrm{AChR}$ localization at synapses, and do additional molecular determinants also contribute to receptor localization? Is $\mathrm{nAChR}$ localization regulated by phosphorylation and does this control the stoichiometry of 14-3-3/nAChR interactions? In addition, what are the key scaffolding protein(s) that anchor 14-3-3/nAChR complexes at PNS synapses? These questions become even more complex when considering nAChR localization in the CNS, as multiple nAChR subtypes with differing subunit compositions are located at diverse subcellular locations on neurons. It seems likely that an array of subunit-specific molecular mechanisms are employed to regulate neuronal nAChR localization in vertebrate neurons, and this would presumably involve distinct binding proteins. Unraveling these diverse mechanisms remain an important challenge which is critical to understanding the nAChR function in both the PNS and CNS.

Funding: Relevant research in the author's laboratory was funded by NIH, grant number NS049354 and the APC was funded by the Department of Anesthesiology and Pain Medicine.

Acknowledgments: I thank the previous members of the Ferns laboratory for their contributions to the work cited, and Lucia Borges for the helpful comments on the manuscript.

Conflicts of Interest: The author declares no conflict of interest.

$\begin{array}{ll}\text { Abbreviations } \\ \text { APC } & \text { adenomatous polyposis coli } \\ \text { CNS } & \text { central nervous system } \\ \text { CMS } & \text { congenital myasthenic syndrome } \\ \text { ICD } & \text { intracellular domain } \\ \text { nAChR } & \text { nicotinic acetylcholine receptor } \\ \text { NMJ } & \text { neuromuscular junction } \\ \text { PNS } & \text { peripheral nervous system } \\ \text { PM } & \text { plasma membrane } \\ \text { TM } & \text { transmembrane }\end{array}$

\section{References}

1. Sine, S.M. End-plate acetylcholine receptor: Structure, mechanism, pharmacology, and disease. Physiol. Rev. 2012, 92, 1189-1234. [CrossRef]

2. Zoli, M.; Pucci, S.; Vilella, A.; Gotti, C. Neuronal and Extraneuronal Nicotinic Acetylcholine Receptors. Curr. Neuropharmacol. 2018, 16, 338-349. [CrossRef]

3. Dani, J.A.; Bertrand, D. Nicotinic acetylcholine receptors and nicotinic cholinergic mechanisms of the central nervous system. Annu. Rev. Pharm. Toxicol. 2007, 47, 699-729. [CrossRef]

4. Albuquerque, E.X.; Pereira, E.F.; Alkondon, M.; Rogers, S.W. Mammalian nicotinic acetylcholine receptors: From structure to function. Physiol. Rev. 2009, 89, 73-120. [CrossRef]

5. Vincent, A. Unravelling the pathogenesis of myasthenia gravis. Nat. Rev. Immunol. 2002, 2, 797-804. [CrossRef] 
6. Engel, A.G.; Shen, X.M.; Selcen, D.; Sine, S.M. Congenital myasthenic syndromes: Pathogenesis, diagnosis, and treatment. Lancet. Neurol. 2015, 14, 461. [CrossRef]

7. Papke, R.L.; Lindstrom, J.M. Nicotinic acetylcholine receptors: Conventional and unconventional ligands and signaling. Neuropharmacology 2020, 168, 108021. [CrossRef] [PubMed]

8. Millar, N.S.; Harkness, P.C. Assembly and trafficking of nicotinic acetylcholine receptors (Review). Mol. Membr. Biol. 2008, 25, 279-292. [CrossRef] [PubMed]

9. Stokes, C.; Treinin, M.; Papke, R.L. Looking below the surface of nicotinic acetylcholine receptors. Trends Pharm. Sci. 2015, 36, 514-523. [CrossRef]

10. Rahman, M.M.; Teng, J.; Worrell, B.T.; Noviello, C.M.; Lee, M.; Karlin, A.; Stowell, M.H.B.; Hibbs, R.E. Structure of the Native Muscle-type Nicotinic Receptor and Inhibition by Snake Venom Toxins. Neuron 2020, 106, 952-962.e955. [CrossRef]

11. Miyazawa, A.; Fujiyoshi, Y.; Stowell, M.; Unwin, N. Nicotinic acetylcholine receptor at 4.6 A resolution: Transverse tunnels in the channel wall. J. Mol. Biol. 1999, 288, 765-786. [CrossRef] [PubMed]

12. Unwin, N. Refined structure of the nicotinic acetylcholine receptor at 4A resolution. J. Mol. Biol. 2005, 346, 967-989. [CrossRef]

13. Noviello, C.M.; Gharpure, A.; Mukhtasimova, N.; Cabuco, R.; Baxter, L.; Borek, D.; Sine, S.M.; Hibbs, R.E. Structure and gating mechanism of the alpha7 nicotinic acetylcholine receptor. Cell 2021. [CrossRef]

14. Gharpure, A.; Teng, J.; Zhuang, Y.; Noviello, C.M.; Walsh, R.M., Jr.; Cabuco, R.; Howard, R.J.; Zaveri, N.T.; Lindahl, E.; Hibbs, R.E. Agonist Selectivity and Ion Permeation in the alpha3beta4 Ganglionic Nicotinic Receptor. Neuron 2019, 104, 501-511.e506. [CrossRef]

15. Morales-Perez, C.L.; Noviello, C.M.; Hibbs, R.E. X-ray structure of the human alpha4beta2 nicotinic receptor. Nature 2016, 538, 411-415. [CrossRef]

16. Miller, P.S.; Aricescu, A.R. Crystal structure of a human GABAA receptor. Nature 2014, 512, 270-275. [CrossRef]

17. Huang, X.; Chen, H.; Michelsen, K.; Schneider, S.; Shaffer, P.L. Crystal structure of human glycine receptor-alpha3 bound to antagonist strychnine. Nature 2015, 526, 277-280. [CrossRef] [PubMed]

18. Hassaine, G.; Deluz, C.; Grasso, L.; Wyss, R.; Tol, M.B.; Hovius, R.; Graff, A.; Stahlberg, H.; Tomizaki, T.; Desmyter, A.; et al. X-ray structure of the mouse serotonin 5-HT3 receptor. Nature 2014, 512, 276-281. [CrossRef]

19. Gharpure, A.; Noviello, C.M.; Hibbs, R.E. Progress in nicotinic receptor structural biology. Neuropharmacology 2020, $171,108086$. [CrossRef]

20. Wu, Z.S.; Cheng, H.; Jiang, Y.; Melcher, K.; Xu, H.E. Ion channels gated by acetylcholine and serotonin: Structures, biology, and drug discovery. Acta. Pharm. Sin. 2015, 36, 895-907. [CrossRef]

21. Unwin, N. Nicotinic acetylcholine receptor and the structural basis of neuromuscular transmission: Insights from Torpedo postsynaptic membranes. Q. Rev. Biophys. 2013, 46, 283-322. [CrossRef] [PubMed]

22. Verschuuren, J.; Strijbos, E.; Vincent, A. Neuromuscular junction disorders. Handb. Clin. Neurol. 2016, 133, 447-466. [CrossRef]

23. Engel, A.G. Genetic basis and phenotypic features of congenital myasthenic syndromes. Handb. Clin. Neurol. 2018, 148, 565-589. [CrossRef]

24. Glass, D.J.; Bowen, D.C.; Stitt, T.N.; Radziejewski, C.; Bruno, J.; Ryan, T.E.; Gies, D.R.; Shah, S.; Mattsson, K.; Burden, S.J.; et al. Agrin acts via a MuSK receptor complex. Cell 1996, 85, 513-523. [CrossRef]

25. Kim, N.; Stiegler, A.L.; Cameron, T.O.; Hallock, P.T.; Gomez, A.M.; Huang, J.H.; Hubbard, S.R.; Dustin, M.L.; Burden, S.J. Lrp4 is a receptor for Agrin and forms a complex with MuSK. Cell 2008, 135, 334-342. [CrossRef]

26. Zhang, B.; Luo, S.; Wang, Q.; Suzuki, T.; Xiong, W.C.; Mei, L. LRP4 serves as a coreceptor of agrin. Neuron 2008, 60, 285-297. [CrossRef]

27. Beeson, D.; Higuchi, O.; Palace, J.; Cossins, J.; Spearman, H.; Maxwell, S.; Newsom-Davis, J.; Burke, G.; Fawcett, P.; Motomura, M.; et al. Dok-7 mutations underlie a neuromuscular junction synaptopathy. Science 2006, 313, 1975-1978. [CrossRef] [PubMed]

28. Okada, K.; Inoue, A.; Okada, M.; Murata, Y.; Kakuta, S.; Jigami, T.; Kubo, S.; Shiraishi, H.; Eguchi, K.; Motomura, M.; et al. The muscle protein Dok-7 is essential for neuromuscular synaptogenesis. Science 2006, 312, 1802-1805. [CrossRef]

29. Linnoila, J.; Wang, Y.; Yao, Y.; Wang, Z.-Z. A Mammalian Homolog of Drosophila Tumorous Imaginal Discs, Tid1, Mediates Agrin Signaling at the Neuromuscular Junction. Neuron 2008, 60, 625-641. [CrossRef] [PubMed]

30. Hallock, P.T.; Xu, C.F.; Park, T.J.; Neubert, T.A.; Curran, T.; Burden, S.J. Dok-7 regulates neuromuscular synapse formation by recruiting Crk and Crk-L. Genes Dev. 2010, 24, 2451-2461. [CrossRef] [PubMed]

31. Luo, Z.G.; Wang, Q.; Zhou, J.Z.; Wang, J.; Luo, Z.; Liu, M.; He, X.; Wynshaw-Boris, A.; Xiong, W.C.; Lu, B.; et al. Regulation of AChR clustering by Dishevelled interacting with MuSK and PAK1. Neuron 2002, 35, 489-505. [CrossRef]

32. Weston, C.; Yee, B.; Hod, E.; Prives, J. Agrin-induced acetylcholine receptor clustering is mediated by the small guanosine triphosphatases Rac and Cdc42. J. Cell Biol. 2000, 150, 205-212. [CrossRef]

33. Weston, C.; Gordon, C.; Teressa, G.; Hod, E.; Ren, X.D.; Prives, J. Cooperative regulation by Rac and Rho of agrin-induced acetylcholine receptor clustering in muscle cells. J. Biol. Chem. 2003, 278, 6450-6455. [CrossRef]

34. Gautam, M.; Noakes, P.G.; Moscoso, L.; Rupp, F.; Scheller, R.H.; Merlie, J.P.; Sanes, J.R. Defective neuromuscular synaptogenesis in agrin-deficient mutant mice. Cell 1996, 85, 525-535. [CrossRef]

35. DeChiara, T.M.; Bowen, D.C.; Valenzuela, D.M.; Simmons, M.V.; Poueymirou, W.T.; Thomas, S.; Kinetz, E.; Compton, D.L.; Rojas, E.; Park, J.S.; et al. The receptor tyrosine kinase MuSK is required for neuromuscular junction formation in vivo. Cell 1996, 85 , 501-512. [CrossRef] 
36. Weatherbee, S.D.; Anderson, K.V.; Niswander, L.A. LDL-receptor-related protein 4 is crucial for formation of the neuromuscular junction. Development 2006, 133, 4993-5000. [CrossRef] [PubMed]

37. Lin, W.; Dominguez, B.; Yang, J.; Aryal, P.; Brandon, E.P.; Gage, F.H.; Lee, K.F. Neurotransmitter acetylcholine negatively regulates neuromuscular synapse formation by a Cdk5-dependent mechanism. Neuron 2005, 46, 569-579. [CrossRef]

38. Misgeld, T.; Kummer, T.T.; Lichtman, J.W.; Sanes, J.R. Agrin promotes synaptic differentiation by counteracting an inhibitory effect of neurotransmitter. Proc. Natl. Acad. Sci. USA 2005, 102, 11088-11093. [CrossRef]

39. Fu, A.K.; Ip, F.C.; Fu, W.Y.; Cheung, J.; Wang, J.H.; Yung, W.H.; Ip, N.Y. Aberrant motor axon projection, acetylcholine receptor clustering, and neurotransmission in cyclin-dependent kinase 5 null mice. Proc. Natl. Acad. Sci. USA 2005, 102, 15224-15229. [CrossRef] [PubMed]

40. Yang, J.; Dominguez, B.; de Winter, F.; Gould, T.W.; Eriksson, J.E.; Lee, K.F. Nestin negatively regulates postsynaptic differentiation of the neuromuscular synapse. Nat. Neurosci. 2011, 14, 324-330. [CrossRef]

41. Mohseni, P.; Sung, H.-K.; Murphy, A.J.; Laliberte, C.L.; Pallari, H.-M.; Henkelman, M.; Georgiou, J.; Xie, G.; Quaggin, S.E.; Thorner, P.S.; et al. Nestin Is Not Essential for Development of the CNS But Required for Dispersion of Acetylcholine Receptor Clusters at the Area of Neuromuscular Junctions. J. Neurosci. 2011, 31, 11547-11552. [CrossRef]

42. Froehner, S.C.; Gulbrandsen, V.; Hyman, C.; Jeng, A.Y.; Neubig, R.R.; Cohen, J.B. Immunofluorescence localization at the mammalian neuromuscular junction of the $\mathrm{Mr} 43,000$ protein of Torpedo postsynaptic membranes. Proc. Natl. Acad. Sci. USA 1981, 78, 5230-5234. [CrossRef]

43. Burden, S.J. The subsynaptic 43-kDa protein is concentrated at developing nerve-muscle synapses in vitro. Proc. Natl. Acad. Sci. USA 1985, 82, 8270-8273. [CrossRef] [PubMed]

44. Noakes, P.G.; Phillips, W.D.; Hanley, T.A.; Sanes, J.R.; Merlie, J.P. 43K protein and acetylcholine receptors colocalize during the initial stages of neuromuscular synapse formation in vivo. Dev. Biol. 1993, 155, 275-280. [CrossRef]

45. LaRochelle, W.J.; Froehner, S.C. Determination of the tissue distributions and relative concentrations of the postsynaptic 43kDa protein and the acetylcholine receptor in Torpedo. J. Biol. Chem. 1986, 261, 5270-5274. [CrossRef]

46. Burden, S.J.; DePalma, R.L.; Gottesman, G.S. Crosslinking of proteins in acetylcholine receptor-rich membranes: Association between the beta-subunit and the $43 \mathrm{kd}$ subsynaptic protein. Cell 1983, 35, 687-692. [CrossRef]

47. Froehner, S.C.; Luetje, C.W.; Scotland, P.B.; Patrick, J. The postsynaptic 43K protein clusters muscle nicotinic acetylcholine receptors in Xenopus oocytes. Neuron 1990, 5, 403-410. [CrossRef]

48. Phillips, W.P.; Kopta, C.; Blount, P.; Gardner, P.D.; Steinbach, J.H.; Merlie, J.P. ACh receptor-rich membrane domains organized in fibroblasts by recombinant 43-kilodalton protein. Science 1991, 251, 568-570. [CrossRef] [PubMed]

49. Gautam, M.; Noakes, P.G.; Mudd, J.; Nichol, M.; Chu, G.C.; Sanes, J.R.; Merlie, J.P. Failure of postsynaptic specialization to develop at neuromuscular junctions of rapsyn-deficient mice. Nature 1995, 377, 232-236. [CrossRef]

50. Ohno, K.; Engel, A.G.; Shen, X.M.; Selcen, D.; Brengman, J.; Harper, C.M.; Tsujino, A.; Milone, M. Rapsyn Mutations in Humans Cause Endplate Acetylcholine-Receptor Deficiency and Myasthenic Syndrome. Am. J. Hum. Genet 2002, 70, 4. [CrossRef]

51. Maselli, R.A.; Dunne, V.; Pascual-Pascual, S.I.; Bowe, C.; Agius, M.; Frank, R.; Wollmann, R.L. Rapsyn mutations in myasthenic syndrome due to impaired receptor clustering. Muscle Nerve 2003, 28, 293-301. [CrossRef]

52. Ramarao, M.K.; Bianchetta, M.J.; Lanken, J.; Cohen, J.B. Role of rapsyn tetratricopeptide repeat and coiled-coil domains in selfassociation and nicotinic acetylcholine receptor clustering. J. Biol. Chem. 2001, 276, 7475-7483. [CrossRef]

53. Ramarao, M.K.; Cohen, J.B. Mechanism of nicotinic acetylcholine receptor cluster formation by rapsyn. Proc. Natl. Acad. Sci. USA 1998, 95, 4007-4012. [CrossRef]

54. Li, L.; Cao, Y.; Wu, H.; Ye, X.; Zhu, Z.; Xing, G.; Shen, C.; Barik, A.; Zhang, B.; Xie, X.; et al. Enzymatic Activity of the Scaffold Protein Rapsyn for Synapse Formation. Neuron 2016, 92, 1007-1019. [CrossRef] [PubMed]

55. Muller, J.S.; Mihaylova, V.; Abicht, A.; Lochmuller, H. Congenital myasthenic syndromes: Spotlight on genetic defects of neuromuscular transmission. Expert Rev. Mol. Med. 2007, 9, 1-20. [CrossRef]

56. Beeson, D.; Webster, R.; Cossins, J.; Lashley, D.; Spearman, H.; Maxwell, S.; Slater, C.R.; Newsom-Davis, J.; Palace, J.; Vincent, A. Congenital myasthenic syndromes and the formation of the neuromuscular junction. Ann. New York Acad. Sci. 2008, 1132, 99-103. [CrossRef]

57. Apel, E.D.; Glass, D.J.; Moscoso, L.M.; Yancopoulos, G.D.; Sanes, J.R. Rapsyn is required for MuSK signaling and recruits synaptic components to a MuSK-containing scaffold. Neuron 1997, 18, 623-635. [CrossRef]

58. Bartoli, M.; Ramarao, M.K.; Cohen, J.B. Interactions of the rapsyn RING-H2 domain with dystroglycan. J. Biol. Chem. 2001, 276, 24911-24917. [CrossRef]

59. Cartaud, A.; Coutant, S.; Petrucci, T.C.; Cartaud, J. Evidence for in situ and in vitro association between beta-dystroglycan and the subsynaptic 43K rapsyn protein. Consequence for acetylcholine receptor clustering at the synapse. J. Biol. Chem. 1998, 273, 11321-11326. [CrossRef] [PubMed]

60. Dobbins, G.C.; Luo, S.; Yang, Z.; Xiong, W.C.; Mei, L. alpha-Actinin interacts with rapsyn in agrin-stimulated AChR clustering. Mol. Brain 2008, 1, 18. [CrossRef]

61. Oury, J.; Liu, Y.; Topf, A.; Todorovic, S.; Hoedt, E.; Preethish-Kumar, V.; Neubert, T.A.; Lin, W.; Lochmuller, H.; Burden, S.J. MACF1 links Rapsyn to microtubule- and actin-binding proteins to maintain neuromuscular synapses. J. Cell Biol. 2019, 218, 1686-1705. [CrossRef] 
62. Antolik, C.; Catino, D.H.; O’Neill, A.M.; Resneck, W.G.; Ursitti, J.A.; Bloch, R.J. The actin binding domain of ACF7 binds directly to the tetratricopeptide repeat domains of rapsyn. Neuroscience 2007, 145, 56-65. [CrossRef] [PubMed]

63. Mihailovska, E.; Raith, M.; Valencia, R.G.; Fischer, I.; Al Banchaabouchi, M.; Herbst, R.; Wiche, G. Neuromuscular synapse integrity requires linkage of acetylcholine receptors to postsynaptic intermediate filament networks via rapsyn-plectin $1 \mathrm{f}$ complexes. Mol. Biol. Cell. 2014, 25, 4130-4149. [CrossRef] [PubMed]

64. Bignami, F.; Camus, G.; Marchand, S.; Bailly, L.; Stetzkowski-Marden, F.; Cartaud, J. Targeting of acetylcholine receptor and 43 kDa rapsyn to the postsynaptic membrane in Torpedo marmorata electrocyte. J. Physiol. Paris 1998, 92, 177-181. [CrossRef]

65. Marchand, S.; Bignami, F.; Stetzkowski-Marden, F.; Cartaud, J. The myristoylated protein rapsyn is cotargeted with the nicotinic acetylcholine receptor to the postsynaptic membrane via the exocytic pathway. J. Neurosci. 2000, 20, 521-528. [CrossRef] [PubMed]

66. Marchand, S.; Devillers-Thiery, A.; Pons, S.; Changeux, J.P.; Cartaud, J. Rapsyn escorts the nicotinic acetylcholine receptor along the exocytic pathway via association with lipid rafts. J. Neurosci. 2002, 22, 8891-8901. [CrossRef]

67. Park, J.Y.; Ikeda, H.; Ikenaga, T.; Ono, F. Acetylcholine receptors enable the transport of rapsyn from the Golgi complex to the plasma membrane. J. Neurosci. 2012, 32, 7356-7363. [CrossRef]

68. Chen, P.J.; Martinez-Pena, Y.V.I.; Aittaleb, M.; Akaaboune, M. AChRs Are Essential for the Targeting of Rapsyn to the Postsynaptic Membrane of NMJs in Living Mice. J Neurosci 2016, 36, 5680-5685. [CrossRef]

69. Moransard, M.; Borges, L.S.; Willmann, R.; Marangi, P.A.; Brenner, H.R.; Ferns, M.J.; Fuhrer, C. Agrin regulates rapsyn interaction with surface acetylcholine receptors, and this underlies cytoskeletal anchoring and clustering. J. Biol. Chem. 2003, 278, 7350-7359. [CrossRef]

70. Xing, G.; Xiong, W.C.; Mei, L. Rapsyn as a signaling and scaffolding molecule in neuromuscular junction formation and maintenance. Neurosci. Lett. 2020, 731, 135013. [CrossRef]

71. Gervasio, O.L.; Armson, P.F.; Phillips, W.D. Developmental increase in the amount of rapsyn per acetylcholine receptor promotes postsynaptic receptor packing and stability. Dev. Biol. 2007, 305, 262-275. [CrossRef] [PubMed]

72. Brockhausen, J.; Cole, R.N.; Gervasio, O.L.; Ngo, S.T.; Noakes, P.G.; Phillips, W.D. Neural agrin increases postsynaptic ACh receptor packing by elevating rapsyn protein at the mouse neuromuscular synapse. Dev. Neurobiol. 2008, 68, 1153-1169. [CrossRef] [PubMed]

73. Gervasio, O.L.; Phillips, W.D. Increased ratio of rapsyn to ACh receptor stabilizes postsynaptic receptors at the mouse neuromuscular synapse. J. Physiol. 2005, 562, 673-685. [CrossRef]

74. Maimone, M.M.; Merlie, J.P. Interaction of the $43 \mathrm{kd}$ postsynaptic protein with all subunits of the muscle nicotinic acetylcholine receptor. Neuron 1993, 11, 53-66. [CrossRef]

75. Huebsch, K.A.; Maimone, M.M. Rapsyn-mediated clustering of acetylcholine receptor subunits requires the major cytoplasmic loop of the receptor subunits. J. Neurobiol. 2003, 54, 486-501. [CrossRef]

76. Lee, Y.; Rudell, J.; Ferns, M. Rapsyn interacts with the muscle acetylcholine receptor via alpha-helical domains in the alpha, beta, and epsilon subunit intracellular loops. Neuroscience 2009, 163, 222-232. [CrossRef]

77. Borges, L.S.; Yechikhov, S.; Lee, Y.I.; Rudell, J.B.; Friese, M.B.; Burden, S.J.; Ferns, M.J. Identification of a motif in the acetylcholine receptor beta subunit whose phosphorylation regulates rapsyn association and postsynaptic receptor localization. J. Neurosci. 2008, 28, 11468-11476. [CrossRef]

78. Koppel, N.; Friese, M.B.; Cardasis, H.L.; Neubert, T.A.; Burden, S.J. Vezatin is required for the maturation of the neuromuscular synapse. Mol. Biol. Cell 2019, 30, 2571-2583. [CrossRef]

79. Luo, S.; Zhang, B.; Dong, X.P.; Tao, Y.; Ting, A.; Zhou, Z.; Meixiong, J.; Luo, J.; Chiu, F.C.; Xiong, W.C.; et al. HSP90 beta regulates rapsyn turnover and subsequent AChR cluster formation and maintenance. Neuron 2008, 60, 97-110. [CrossRef]

80. Zuber, B.; Unwin, N. Structure and superorganization of acetylcholine receptor-rapsyn complexes. Proc. Natl. Acad. Sci. USA 2013, 110, 10622-10627. [CrossRef]

81. $\mathrm{Xu}, \mathrm{J} . ; \mathrm{Zhu}, \mathrm{Y}$.; Heinemann, S.F. Identification of sequence motifs that target neuronal nicotinic receptors to dendrites and axons. J. Neurosci. 2006, 26, 9780-9793. [CrossRef]

82. Johnson, B.; Leek, A.N.; Sole, L.; Maverick, E.E.; Levine, T.P.; Tamkun, M.M. Kv2 potassium channels form endoplasmic reticulum/plasma membrane junctions via interaction with VAPA and VAPB. Proc. Natl. Acad. Sci. USA 2018, 115, E7331-E7340. [CrossRef]

83. Feng, G.; Steinbach, J.H.; Sanes, J.R. Rapsyn clusters neuronal acetylcholine receptors but is inessential for formation of an interneuronal cholinergic synapse. J. Neurosci. 1998, 18, 4166-4176. [CrossRef]

84. Kassner, P.D.; Conroy, W.G.; Berg, D.K. Organizing effects of rapsyn on neuronal nicotinic acetylcholine receptors. Mol. Cell. Neurosci. 1998, 10, 258-270. [CrossRef] [PubMed]

85. Yang, S.H.; Armson, P.F.; Cha, J.; Phillips, W.D. Clustering Of Gaba(a) Receptors By Rapsyn/43kd Protein In Vitro. Mol. Cell. Neurosci. 1997, 8, 430-438. [CrossRef] [PubMed]

86. Quiram, P.A.; Ohno, K.; Milone, M.; Patterson, M.C.; Pruitt, N.J.; Brengman, J.M.; Sine, S.M.; Engel, A.G. Mutation causing congenital myasthenia reveals acetylcholine receptor beta/delta subunit interaction essential for assembly. J. Clin. Investig. 1999, 104, 1403-1410. [CrossRef]

87. Wang, J.; Jing, Z.; Zhang, L.; Zhou, G.; Braun, J.; Yao, Y.; Wang, Z.Z. Regulation of acetylcholine receptor clustering by the tumor suppressor APC. Nat. Neurosci. 2003, 6, 1017-1018. [CrossRef] 
88. Borges, L.S.; Ferns, M. Agrin-induced phosphorylation of the acetylcholine receptor regulates cytoskeletal anchoring and clustering. J. Cell Biol. 2001, 153, 1-11. [CrossRef]

89. Friese, M.B.; Blagden, C.S.; Burden, S.J. Synaptic differentiation is defective in mice lacking acetylcholine receptor beta-subunit tyrosine phosphorylation. Development 2007, 134, 4167-4176. [CrossRef]

90. Mitra, A.K.; McCarthy, M.P.; Stroud, R.M. Three-dimensional structure of the nicotinic acetylcholine receptor and location of the major associated $43-\mathrm{kD}$ cytoskeletal protein, determined at $22 \mathrm{~A}$ by low dose electron microscopy and $\mathrm{x}$-ray diffraction to $12.5 \mathrm{~A}$. J. Cell Biol. 1989, 109, 755-774. [CrossRef]

91. Apel, E.D.; Roberds, S.L.; Campbell, K.P.; Merlie, J.P. Rapsyn may function as a link between the acetylcholine receptor and the agrin-binding dystrophin-associated glycoprotein complex. Neuron 1995, 15, 115-126. [CrossRef]

92. Wang, Z.Z.; Mathias, A.; Gautam, M.; Hall, Z.W. Metabolic stabilization of muscle nicotinic acetylcholine receptor by rapsyn. J. Neurosci. 1999, 19, 1998-2007. [CrossRef]

93. Rudell, J.B.; Ferns, M.J. Regulation of muscle acetylcholine receptor turnover by beta subunit tyrosine phosphorylation. Dev. Neurobiol. 2013, 73, 399-410. [CrossRef]

94. Bruneau, E.; Akaaboune, M. The dynamics of the rapsyn scaffolding protein at individual acetylcholine receptor clusters. J. Biol. Chem. 2007, 282, 9932-9940. [CrossRef]

95. Bruneau, E.G.; Akaaboune, M. Dynamics of the rapsyn scaffolding protein at the neuromuscular junction of live mice. J. Neurosci. 2010, 30, 614-619. [CrossRef]

96. Nam, S.; Min, K.; Hwang, H.; Lee, H.O.; Lee, J.H.; Yoon, J.; Lee, H.; Park, S.; Lee, J. Control of rapsyn stability by the CUL-3containing E3 ligase complex. J. Biol. Chem. 2009, 284, 8195-8206. [CrossRef]

97. Wang, N.; Orr-Urtreger, A.; Korczyn, A.D. The role of neuronal nicotinic acetylcholine receptor subunits in autonomic ganglia: Lessons from knockout mice. Prog. Neurobiol. 2002, 68, 341-360. [CrossRef]

98. Xu, W.; Gelber, S.; Orr-Urtreger, A.; Armstrong, D.; Lewis, R.A.; Ou, C.N.; Patrick, J.; Role, L.; De Biasi, M.; Beaudet, A.L. Megacystis, mydriasis, and ion channel defect in mice lacking the alpha3 neuronal nicotinic acetylcholine receptor. Proc. Natl. Acad. Sci. USA 1999, 96, 5746-5751. [CrossRef]

99. Xu, W.; Orr-Urtreger, A.; Nigro, F.; Gelber, S.; Sutcliffe, C.B.; Armstrong, D.; Patrick, J.W.; Role, L.W.; Beaudet, A.L.; De Biasi, M. Multiorgan autonomic dysfunction in mice lacking the beta2 and the beta4 subunits of neuronal nicotinic acetylcholine receptors. J. Neurosci. 1999, 19, 9298-9305. [CrossRef]

100. Rassadi, S.; Krishnaswamy, A.; Pie, B.; McConnell, R.; Jacob, M.H.; Cooper, E. A null mutation for the alpha3 nicotinic acetylcholine $(\mathrm{ACh})$ receptor gene abolishes fast synaptic activity in sympathetic ganglia and reveals that ACh output from developing preganglionic terminals is regulated in an activity-dependent retrograde manner. J. Neurosci. 2005, 25, 8555-8566. [CrossRef]

101. Zhang, Z.W.; Coggan, J.S.; Berg, D.K. Synaptic currents generated by neuronal acetylcholine receptors sensitive to alphabungarotoxin. Neuron 1996, 17, 1231-1240. [CrossRef]

102. Gingras, J.; Rassadi, S.; Cooper, E.; Ferns, M. Agrin plays an organizing role in the formation of sympathetic synapses. J. Cell Biol. 2002, 158, 1109-1118. [CrossRef] [PubMed]

103. Gingras, J.; Rassadi, S.; Cooper, E.; Ferns, M. Synaptic transmission is impaired at neuronal autonomic synapses in agrin-null mice. Dev. Neurobiol. 2007, 67, 521-534. [CrossRef]

104. Martin, A.O.; Alonso, G.; Guerineau, N.C. Agrin mediates a rapid switch from electrical coupling to chemical neurotransmission during synaptogenesis. J. Cell Biol. 2005, 169, 503-514. [CrossRef]

105. Neff, R.A., 3rd; Gomez-Varela, D.; Fernandes, C.C.; Berg, D.K. Postsynaptic scaffolds for nicotinic receptors on neurons. Acta Pharm. Sin. 2009, 30, 694-701. [CrossRef] [PubMed]

106. Williams, B.M.; Temburni, M.K.; Levey, M.S.; Bertrand, S.; Bertrand, D.; Jacob, M.H. The long internal loop of the alpha 3 subunit targets nAChRs to subdomains within individual synapses on neurons in vivo. Nat. Neurosci. 1998, 1, 557-562. [CrossRef] [PubMed]

107. Temburni, M.K.; Blitzblau, R.C.; Jacob, M.H. Receptor targeting and heterogeneity at interneuronal nicotinic cholinergic synapses in vivo. J. Physiol. 2000, 525, 21-29. [CrossRef] [PubMed]

108. Rosenberg, M.M.; Yang, F.; Giovanni, M.; Mohn, J.L.; Temburni, M.K.; Jacob, M.H. Adenomatous polyposis coli plays a key role, in vivo, in coordinating assembly of the neuronal nicotinic postsynaptic complex. Mol. Cell. Neurosci. 2008, 38, 138-152. [CrossRef]

109. Temburni, M.K.; Rosenberg, M.M.; Pathak, N.; McConnell, R.; Jacob, M.H. Neuronal nicotinic synapse assembly requires the adenomatous polyposis coli tumor suppressor protein. J. Neurosci. 2004, 24, 6776-6784. [CrossRef] [PubMed]

110. Parker, M.J.; Zhao, S.; Bredt, D.S.; Sanes, J.R.; Feng, G. PSD93 regulates synaptic stability at neuronal cholinergic synapses. J. Neurosci. 2004, 24, 378-388. [CrossRef]

111. Conroy, W.G.; Liu, Z.; Nai, Q.; Coggan, J.S.; Berg, D.K. PDZ-containing proteins provide a functional postsynaptic scaffold for nicotinic receptors in neurons. Neuron 2003, 38, 759-771. [CrossRef] 